\title{
Hydrogen bonds as an alternative activation
}

Eugenia Marqués-López and Raquel P. Herrera ${ }^{\mathrm{a}, \mathrm{b}}$

${ }^{a}$ Laboratorio de Síntesis Asimétrica, Departamento de Química Orgánica.

Instituto de Síntesis Química y Catálisis Homogénea (ISQCH), CSIC-Universidad de Zaragoza.

E-50009 Zaragoza, Aragón, Spain. Fax: +34 976762075.

${ }^{\mathrm{b}}$ ARAID, Fundación Aragón I+D, E-50004 Zaragoza, Spain.

mmaamarq@unizar.es and raquelph@unizar.es

\section{Introduction}

In the last decade a remarkable expansion of a new field has been accomplished, the asymmetric organocatalysis.[1] This new discipline has appeared as an useful, complementary and alternative strategy between those previously and more broadly explored, the metal and enzymatic catalysis. In this context, an impressive number of highly enantioselective approaches have been successfully and efficiently developed for the most common organic reactions and the synthesis of new complex products has been also achieved.[2]

The immense number of organocatalytic processes could be classified into four big groups depending on the catalyst activation nature as previously proposed by Dalko and Moisan:[3] 1. Reactions via covalent activation complexes, such as those performed with chiral secondary or primary amines;[4] 2. Reactions via non covalent activation transition states, using hydrogen bond catalysis;[5] 3. Enantioselective phase-transfer reactions by chiral quaternary ammonium salts;[6] 4. Asymmetric transformations in a chiral cavity.[7] Among all of them and within the second group, catalysts acting by hydrogen bond interactions represent a significant contribution to this great area, receiving a special attention in the last decade.[5] The main organocatalytic structures covering this large group are thiourea/urea derivatives,[8] guanidines,[9] TADDOL[10] or BINOL analogues,[11] “chiral proton catalysts"[12] and chiral phosphoric acid derivatives.[13] Some of these representative structures are illustrated in Figure 1. 
<smiles>[R]NC(=O)[C@H](CC(C)(C)C)NC(=S)N[C@H]1CCCC[C@H]1/N=C/c1cc([R])cc(C(C)(C)C)c1O</smiles>

Jacobsen's group<smiles>[R]C1CN2CC([R1])NC2=N1</smiles>

$\mathrm{R}^{1}=\mathrm{Ph}, \mathrm{Bn}, t-\mathrm{Bu}$

Corey's group 1999<smiles>CC1(C)OC(C(O)(Br)Br)[C@H](C(O)(Br)Br)[Ge]1</smiles>

Rawal's group 2003

\section{8}<smiles>Oc1c(Br)cc2c(c1-c1c(O)c(Br)cc3c1CCCC3)CCCC2</smiles>

$\mathrm{Ar}=3,5-\left(\mathrm{CH}_{3}\right)_{2}-\mathrm{C}_{6} \mathrm{H}_{3}$ $\mathrm{Ar}=3,5-\left(\mathrm{CF}_{3}\right)_{2}-\mathrm{C}_{6} \mathrm{H}_{3}$

Schaus's group 2003<smiles>O=P1(O)Oc2c(Br)cc3ccccc3c2-c2c(Br)cc3ccccc3c2O1</smiles>

Akiyama's and Terada's group 2004

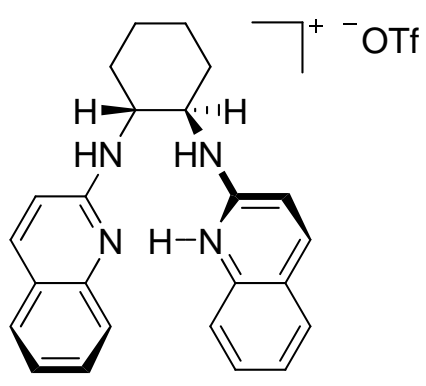

Johnston's group 2004

Figure 1 Representative organocatalysts acting as hydrogen-bond donors

\subsection{Chiral Thiourea/Urea Organocatalysts}

Intensive efforts have been invested in studying the behavior of (thio)urea structures as suitable catalysts in a great number of efficient processes. In this respect, the center of inspiration for the subsequent reactions concerning this area was the work reported by Etter and co-workers where aryl urea $\mathbf{1}$ was able to form cocrystal complexes with a variety of hydrogen bond acceptors (Figure 2).[14]<smiles>O=C(Nc1cccc([N+](=O)[O-])c1)Nc1cccc([N+](=O)[O-])c1</smiles>

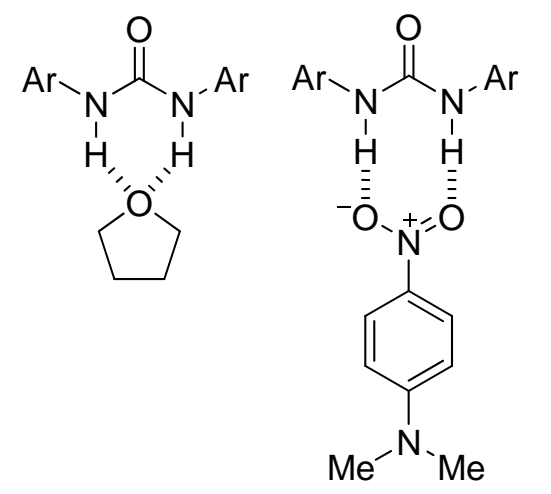

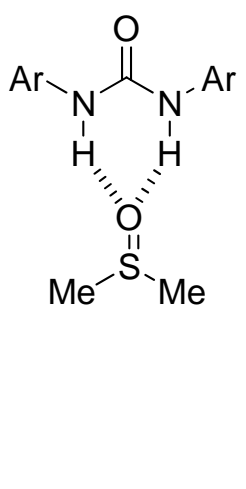

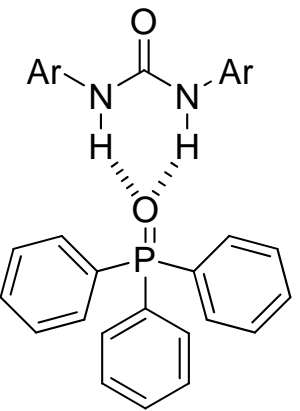

Figure 2 Co-crystallized functional groups using urea 1. Model of bidentate activation 
Nevertheless, the first application of this kind of bidentate activation employing such structures was reported by Curran and co-workers, using urea catalyst $\mathbf{2}$. They observed that the presence of urea $\mathbf{2}$ modified the rate and the stereochemical course of allylation reactions employing cyclic sulfinyl radicals as depicted in Scheme 1.[15] Moreover, urea 2 was also able to accelerate a Claisen rearrangement of electron rich allyl vinyl ethers.[16] Both studies became key works in this growing area and they were a main reference for the following research works using (thio)urea catalysts.

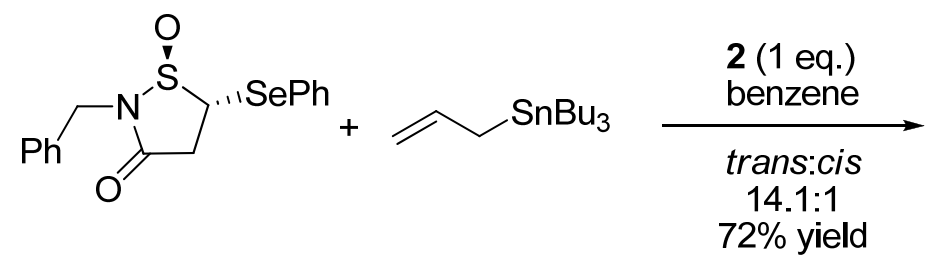<smiles>C=CCC1CC(=O)N(Cc2ccccc2)[C@@H]1O</smiles><smiles>CCOC(=O)c1cc(NC(=O)Nc2cc(C(=O)OCC)cc(C(F)(F)F)c2)cc(C(F)(F)F)c1</smiles>

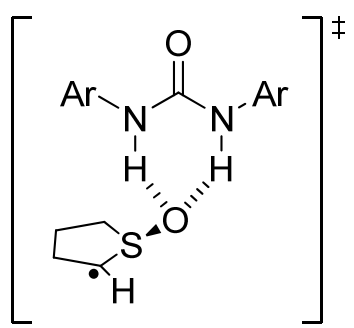

Scheme 1 Allylation reaction promoted by urea 2

However the first examples using hydrogen bond catalysis promoted by bidentate motifs could be attributed to Hine's[17] and Kelly's groups,[18] although in these cases using biphenylenediol derivatives. Ensuing these original examples, a great number of chiral thioureas and several ureas have been developed and effectively applied in a large number of catalytic systems (Figure 3).[8] 
<smiles>FC(F)(F)c1cc(NC(=S)Nc2cc(C(F)(F)F)cc(C(F)(F)F)c2)cc(C(F)(F)F)c1</smiles>

Schreiner 2003<smiles>CN(C)[C@@H]1CCCC[C@H]1NC(=S)Nc1cc(C(F)(F)F)cc(C(F)(F)F)c1</smiles>

Takemoto 2003

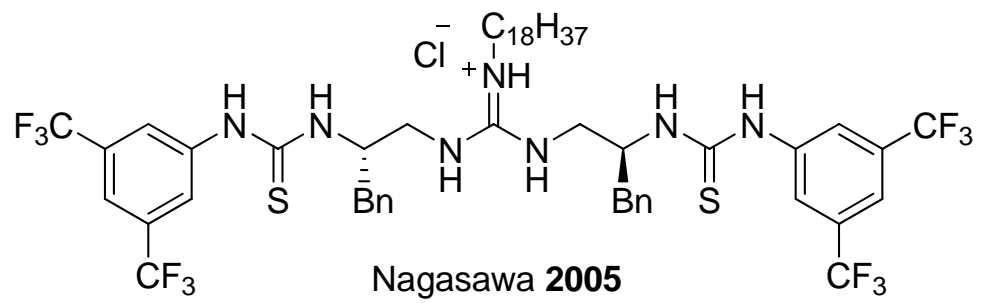<smiles>C=CC1C2CCN1CC2[C@H](NC(N)=S)c1ccnc2ccc(OC)cc12</smiles>

Soós 2005<smiles>Nc1cc(C(F)(F)F)cc(C(F)(F)F)c1</smiles>

Nagasawa 2005<smiles>CC(C)(O)CCCC#N</smiles><smiles>O[C@H]1Cc2ccccc2[C@H]1NC(=S)Nc1cc(C(F)(F)F)cc(C(F)(F)F)c1</smiles>

Ricci 2006<smiles>FC(F)(F)c1cc(Nc2cc(C(F)(F)F)cc(C(F)(F)F)c2)cc(C(F)(F)F)c1</smiles><smiles>NC(N)=S</smiles><smiles>FC(F)(F)c1cc(NC(=S)Nc2ccc3ccccc3c2-c2c(NC(=S)Nc3cc(C(F)(F)F)cc(C(F)(F)F)c3)ccc3ccccc23)cc(C(F)(F)F)c1</smiles><smiles>CN(C)c1ccc2ccccc2c1-c1c(NC(=S)Nc2cc(C(F)(F)F)cc(C(F)(F)F)c2)ccc2ccccc12</smiles>

Figure 3 Representative thiourea catalysts

This chapter will be focused on our own contribution to the emerging area of chiral thiourea catalysis. Our work will be illustrated and discussed by comparison with pioneering models concerning different explored reactions. Diverse developed strategies for the preparation of interesting building-blocks will be highlighted.

\section{Thiourea catalysts}

\subsection{Friedel-Crafts alkylation reaction}

Friedel-Crafts alkylation reaction has become one of the most powerful carbon-carbon bond-forming processes in organic synthesis, mainly by means of metal catalysis,[19] and more scarcely explored by organocatalytic procedures.[20] Among the most significant Friedel-Crafts reactions, those concerning the Michael addition of indoles to electron deficient alkenes have attracted a special attention.[20a] The indole is considered a privileged structure and it is a frequent motif in a great number of natural products (Figure 4)[21] for this reason the development of new enantioselective methodologies for its chiral synthesis is always an important achievement. 


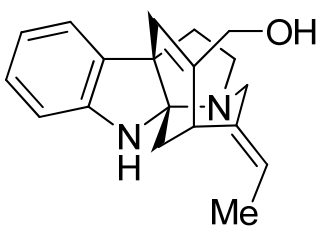

(+)-minfiensine

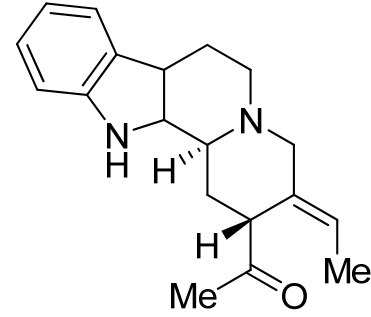

$(-)$-arboricine<smiles>COc1ccc2c(c1)C1(C)CCN(C)C1(C)N2C</smiles>

(+)-esermethole<smiles>COC(=O)[C@@H]1[C@H](O)CC[C@@H]2CN3CCc4c([nH]c5ccccc45)[C@H]3C[C@H]21</smiles>

Figure 4 Indole motifs in natural products

In this context, we developed a pioneering example of organocatalyzed Friedel-Crafts alkylation reaction between nitroolefins and aromatic and heteroaromatic systems.[22] Until that moment, just metal catalyzed examples of this reactions using Lewis acids like $\mathrm{Yb}(\mathrm{OTf})_{3} \cdot 3 \mathrm{H}_{2} \mathrm{O}$, [23] $\mathrm{Sc}(\mathrm{OTf})_{3}[24]$ or $\mathrm{Bi}(\mathrm{OTf})_{3}[25]$ had been reported. We revealed by the first time the useful application of organocatalysis in this process using neutral hydrogen bond donors, urea- and thiourea-type catalysts 3 and 4 respectively (Scheme 2), in a comparative study where all examples were tested in toluene and solventless conditions affording very good yields.<smiles>[R1]n1cccc1</smiles>

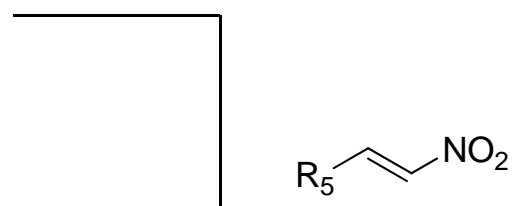

3 or $4(10 \mathrm{~mol} \%)$, r.t. Toluene or solventless<smiles>[R]c1cccc(N([R])[R])c1[R]</smiles><smiles></smiles><smiles>[X][Ga][Ge]</smiles>

$\mathrm{R}_{2}=\mathrm{Et}, \mathrm{Me},-\mathrm{CH}_{2} \mathrm{CH}_{2}-$

$\mathrm{R}_{4}=\mathrm{H}, \mathrm{OMe},-\mathrm{CH}=\mathrm{CH}-$

$$
X=O(3), S(4)
$$<smiles>[R6]C(C[N+](=O)[O-])c1cccn1[R]</smiles>

yield up to $86 \%$<smiles>[R]c1c(C([R3])C[N+](=O)[O-])ccc(N([R])[R])c1[R]</smiles>

$\mathrm{R}_{1}=\mathrm{Me}, \mathrm{Ph}$

$\mathrm{R}_{3}=\mathrm{H},-\mathrm{CH}=\mathrm{CH}-$

$\mathrm{R}_{5}=\mathrm{Ph}, \mathrm{C}_{5} \mathrm{H}_{11}$

Scheme 2 Organocatalyzed Friedel-Crafts alkylation reaction of aromatic and heteroaromatic systems

We also turned our attention to the Friedel-Crafts alkylation of indoles (Scheme 3), because only a practical and efficient $\mathrm{InBr}_{3}$-catalyzed addition of indoles to nitroalkenes in aqueous media had been formerly reported.[26] 
<smiles>[R]c1cc2ccccc2n1[R1]</smiles>

$\mathrm{R}^{1}=\mathrm{H}, \mathrm{Me}$

$\mathrm{R}^{2}=\mathrm{H}, \mathrm{Me}$

$\mathrm{R}^{3}=\mathrm{Ph}, \mathrm{C}_{5} \mathrm{H}_{11}$<smiles>[R]c1c(C([R])C[N+](=O)[O-])c2ccccc2n1[R]</smiles>

yield up to quantitative

Scheme 3 Friedel-Crafts alkylation reaction of indoles with nitroalkenes

The outcomes using thiourea organocatalyst 4 resulted superior in all cases with respect to those obtained employing urea 3. This tendency was in agreement with the greater hydrogen-bond donor ability of thiourea derivatives supported by the enhanced differences in acidities $\left(\mathrm{pK}_{\mathrm{HA}}\right.$ thiourea $=21.0 ; \mathrm{pK}_{\mathrm{HA}}$ urea $=26.9$ ).[27] Furthermore, the less tendency of sulfur atom to make self-association between the $\mathrm{N}-\mathrm{H}$ group of one molecule with the thiocarbonyl group of another would justify the different results achieved with these catalysts.[28]

In order to explain the mode of activation, a similar double hydrogen-bond interaction between the (thio)urea-type derivatives with the nitro group was proposed in analogy to the hypothesis reported earlier for this functional group (Figure 5).[14]

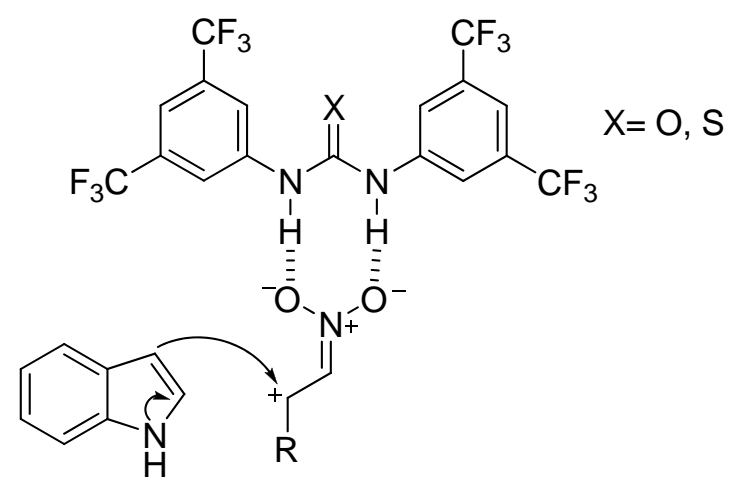

Figure 5 Mechanistic hypothesis

More interesting was the original development of the enantioselective version of the latter Friedel-Crafts alkylation reaction.[29] For this purpose the synthesis of simple and easily accessible chiral (thio)urea catalysts was required. Initially we prepared and screened catalysts 7a-g (Scheme 4), easily obtained in one step of reaction and in very good yields from the coupling reaction between 3,5-bis(trifluoromethyl)phenyl iso(thio)cyanate 5 or $\mathbf{6}$ and the corresponding chiral amines or amino alcohols, all commercially available. 


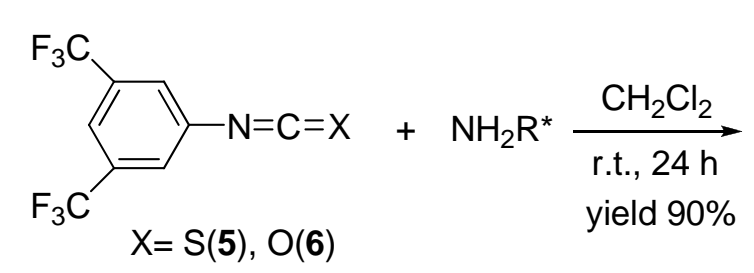<smiles>[R]NC(=[X])Nc1cc(C(F)(F)F)cc(C(F)(F)F)c1</smiles><smiles>OCC(Cc1ccccc1)N[C@H](Cc1cc(C(F)(F)F)cc(C(F)(F)F)c1)C(=S)Nc1cc(C(F)(F)F)cc(C(F)(F)F)c1</smiles><smiles>OC(NC(=S)Nc1cc(C(F)(F)F)cc(C(F)(F)F)c1)C(c1ccccc1)c1ccccc1</smiles>

Scheme 4 Synthesis of chiral (thio)ureas 7a-e

In all cases an increased reactivity of trans- $\beta$-nitrostyrene against indole was achieved with every synthesized catalyst. However, only thiourea catalyst $\mathbf{7 d}$ exhibited promising results in terms of both reactivity and enantioselectivity. After exploring different parameters and under the optimized reaction conditions, we extended our method to diverse indoles and nitroalkenes affording final adducts with very good yields and high enantioselectivities. The scope of the reaction is summarized in Scheme 5. 


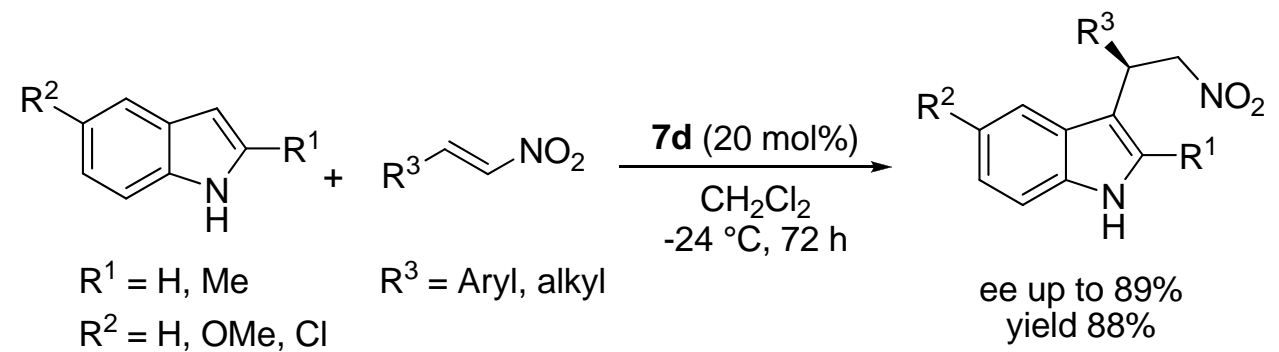<smiles>O=[N+]([O-])C[C@H](c1ccccc1)c1c[nH]c2ccccc12</smiles>

yield $78 \%$ ee $85 \%$<smiles>O=[N+]([O-])C[C@H](c1ccco1)c1c[nH]c2ccccc12</smiles>

yield $88 \%$ ee $73 \%$<smiles>Cc1[nH]c2ccccc2c1[C@H](C[N+](=O)[O-])c1ccccc1</smiles>

yield $82 \%$ ee $74 \%$<smiles>O=[N+]([O-])C[C@H](c1cccs1)c1c[nH]c2ccccc12</smiles>

yield $70 \%$ ee $73 \%$<smiles>COc1ccc2[nH]cc([C@H](C[N+](=O)[O-])c3ccccc3)c2c1</smiles>

yield $86 \%$ ee $89 \%$<smiles>O=[13C]([O-])[C@H](C[N+](=O)[O-])c1c[nH]c2ccccc12</smiles>

yield $76 \%$ ee $83 \%$<smiles>O=[N+]([O-])CC(c1ccccc1)c1c[nH]c2ccc(Cl)cc12</smiles>

yield $35 \%$ ee $71 \%$<smiles>O=[N+]([O-])C[C@H](c1c[nH]c2ccccc12)[P+](=O)[O-]</smiles>

yield $37 \%$ ee $81 \%$

Scheme 5 Thiourea catalyzed Friedel-Crafts alkylation reaction

In order to demonstrate the synthetically valuable aspect of this process, the optically active adduct $\mathbf{8}$ was transformed into important compounds of biological interest such as tryptamine 9[30] and 1,2,3,4-tetrahydro$\beta$-carboline 11[31] in very good yield and without racemization, as represented in Scheme 6. Moreover, derivatization of compound $\mathbf{8}$ in the corresponding $N$-tosylated tryptamine $\mathbf{1 0}$ allowed the assignation of the absolute configuration of the final products.<smiles>O=[N+]([O-])CC(c1ccccc1)c1c[nH]c2ccccc12</smiles>

8

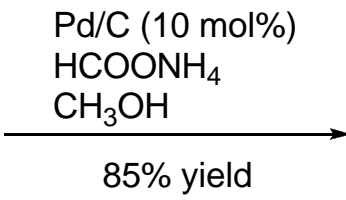

$85 \%$ yield<smiles>NCC(c1ccccc1)c1c[nH]c2ccccc12</smiles>

9

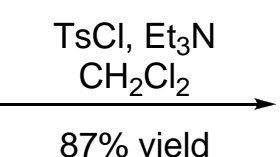

$87 \%$ yield<smiles>CC(C)(C)OC(=S)[SnH2]</smiles>

$1085 \%$ ee

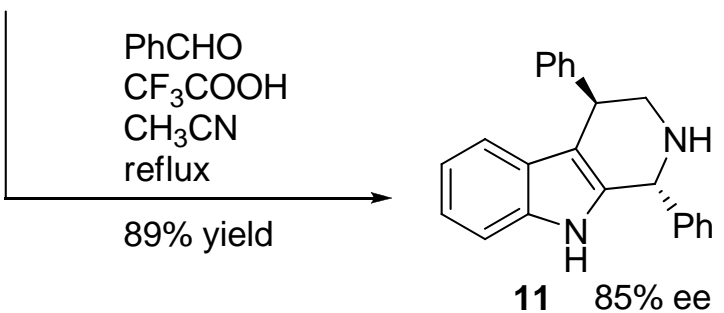

Scheme 6 Synthesis of tryptamine 9 and 1,2,3,4-tetrahydro- $\beta$-carboline 11 
In an attempt to understand the possible mode of action of novel catalyst $\mathbf{7 d}$ in the activation complex that led to the observed enantioinduction in final products, we synthesized catalyst $\mathbf{7 f}$, lacking the alcoholic function, and $7 \mathbf{g}$, in which the hydroxy group was protected by a trimethylsilyl group. Both catalysts showed poorer results in comparison with $\mathbf{7 d}$, not only with regard to the enantioselectivity but also in terms of the catalyst activity, as shown in Figure 6.<smiles>O[C@H]1Cc2ccccc2[C@H]1NC(=S)Nc1cc(C(F)(F)F)cc(C(F)(F)F)c1</smiles><smiles>FC(F)(F)c1cc(NC(=S)N[C@H]2CCc3ccccc32)cc(C(F)(F)F)c1</smiles><smiles>CO[C@H]1Cc2ccccc2[C@H]1NC(=S)Nc1cc(C(F)(F)F)cc(C(F)(F)F)c1</smiles>

\section{Figure 6}

This fact, in addition to the results obtained with different indoles in which the NH in the structure seemed to be also crucial, we envisioned that our catalyst could act as a bifunctional catalyst.[8f,32] Our proposal was that the thiourea would activate the nitro group through the $\mathrm{N}-\mathrm{H}$ atoms, as previously reported, and the hydroxyl function would interact with the indolic proton by means of a weak hydrogen bond, approaching the nucleophile on the Si face of the nitroolefin as depicted in Figure 7. This attack would afford the absolute configuration observed in the final products.

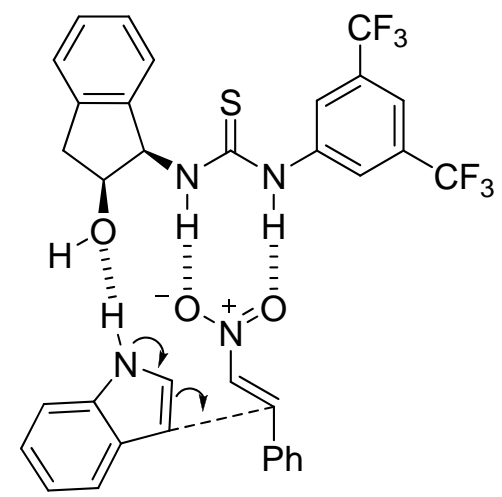

Figure 7 Mechanistic proposal

The rigidity of the aminoindanol skeleton in catalyst $\mathbf{7 d}$ seemed to be also crucial for the success of the process compared with the major flexibility expected by catalyst $\mathbf{s} \mathbf{7 b}$ and $\mathbf{7} \mathbf{c}$ in the transition state, in which the $\mathrm{OH}$ group was also present but affording poorer results overall in terms of enantioselectivities.

Concurrently to our original example, Jørgensen and co-workers[33] and more recently Connon's,[34] Seidel's[35] and Akiyama's[36] groups have developed attractive and efficient catalytic systems; which are bis-sulfonamide 12, bis-thiourea 13, quinolinium thioamide catalyst $\mathbf{1 4}$ and phosphoric acid silyl-derivative 15 respectively, for their applications as promoters in this Friedel-Crafts alkylation reaction (Figure 8). 


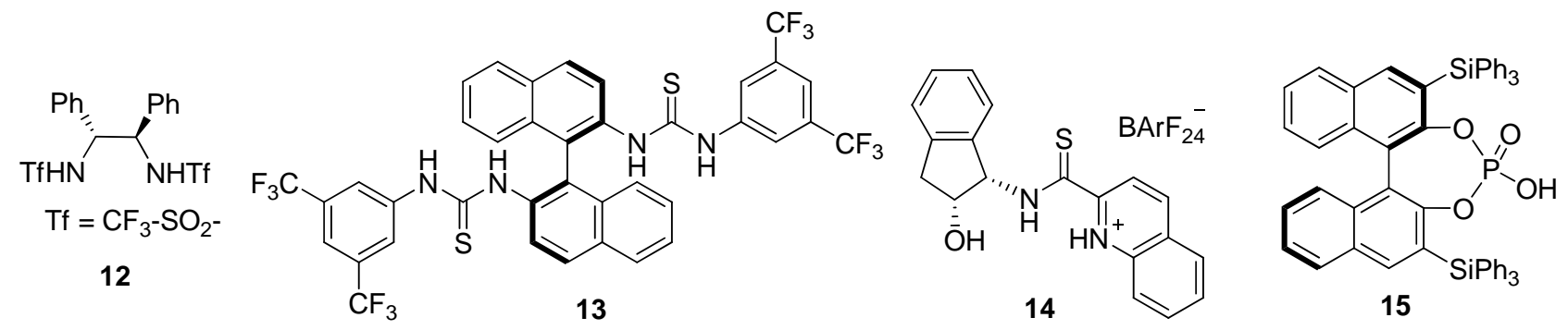

Figure 8 Efficient catalysts for activating the Friedel-Crafts alkylation reaction

Chiral bis-arylthiourea $\mathbf{1 3}$ was employed in the study of the asymmetric organocatalytic Friedel-Crafts addition between $\mathrm{N}$-methylindole and nitroolefines affording low enantioselectivities and good yields after long reaction time. However, with the other catalysts non $N$-substituted indoles were efficient nucleophiles against a range of nitroolefines, being the presence of the N-H moiety in the indole ring essential to achieve high yields and enantioselectivities. Interestingly in all cases a hydrogen donor catalyst was required to promote the reaction.

In spite of the importance of this process, it is still scarcely investigated and documented; therefore the searching for more effective catalysts is still open. Additional investigations are expected to arise in this area for the preparation of asymmetric attractive indole structures.

\subsection{Michael addition reactions}

Among the most significant and common reactions developed so far in organocatalysis, those concerning conjugate Michael additions of a nucleophile to an electron-deficient olefin, are the most relevant ones in this expanding area.[37] This strategy allows the stereoselective formation of carbon-carbon[38] or carbonheteroatom bonds[39] and it has been successfully applied in a great number of reactions. Its synthetic potential has been demonstrated by application in total synthesis and in the obtention of molecules of high complexity.[2,40]

\subsubsection{Michael addition reaction of $N, N$-dialkylhydrazones to nitroalkenes}

Suitable but less explored nucleophiles are the $N, N$-dialkylhydrazones, which may exhibit an ambiphilic behavior: on the one hand demonstrating an aza-enamine character and reacting with electrophiles such as activated Michael acceptors under the appropriate conditions,[41] and on the other hand acting as imine surrogates against nucleophiles. Although, this aspect has been less considered,[42] contrary to the wellknown electrophilic character of $N$-acylhydrazones.[43] As aza-enamines, formaldehyde $N, N$ dialkylhydrazones have been extensively used as synthetic equivalents of formyl and cyanide anions,[44] however and despite their diverse reactivity and synthetic versatility, these privileged species have been less considered in organocatalysis.[45]

In this context, another developed application of thiourea $\mathbf{4}$ is the activation of nucleophilic addition of $N, N$ dialkylhydrazones to diverse nitroolefines.[46] Formaldehyde $N, N$-dialkylhydrazones have been extensively investigated, in comparison with hydrazones synthesized with other aldehydes, which have been barely considered due to their inherent lower reactivity.[42b] We developed a new work in the field of conjugate 
additions using less reactive aliphatic aldehyde hydrazones and nitroalkenes catalyzed by thiourea $\mathbf{4}$ and in absence of base, as depicted in Scheme 7.<smiles>[R]C/C=N\N([R])[R]</smiles><smiles>CN(C)/N=C/CC(C[N+](=O)[O-])c1ccccc1</smiles>

$58 \%$<smiles>CC(/C=N/N(C)C)C(C[N+](=O)[O-])c1ccccc1</smiles>

$77 \%$<smiles>CN(C)/N=C/C(c1ccccc1)C(C[N+](=O)[O-])c1ccccc1</smiles>

$92 \%$<smiles>CC(/C=N/N1CCCC1)C(C[N+](=O)[O-])c1ccccc1</smiles>

$73 \%$ d.r. 7:1 d.r. 5:1 d.r. 6:1<smiles>CCCC(C[N+](=O)[O-])C(C)C(C)N=NN(C)C</smiles><smiles>CCC(C)C(C[N+](=O)[O-])C(C)C(C)/C=N/N(C)C</smiles><smiles>CC(/C=N/N(C)C)C(C[N+](=O)[O-])c1ccc(Br)o1</smiles><smiles>CN(C)N</smiles><smiles>CC(/C=N/N)C(C[N+](=O)[O-])c1cccs1</smiles><smiles>CN(C)/N=C/C(c1ccccc1)C(C[N+](=O)[O-])c1ccco1</smiles>

$82 \%$

d.r. 3:1<smiles>CN(C)/N=C/C(c1ccccc1)C(C[N+](=O)[O-])c1cccs1</smiles>

$75 \%$<smiles>O=[N+]([O-])CC(c1ccco1)C(/C=N/N1CCCC1)c1ccccc1</smiles>

$70 \%$<smiles>O=[N+]([O-])CC(c1cccs1)C(/C=N/N1CCCC1)c1ccccc1</smiles>

$68 \%$

Scheme 7 Michael addition reaction of $N, N$-dialkylhydrazones 16 to nitroalkenes 17

Some remarkable aspects of this process should be underlined: Firstly, we were glad to observe that thiourea 4 promoted the reaction affording higher yield values at the same reaction time that the uncatalyzed reaction. Surprisingly, instead of the formation of the expected products from the attack by the azomethine carbon atom of the hydrazone, as it had been observed with formaldehyde hydrazone derivatives, we obtained the products resulting from the nucleophilic attack at the $\alpha$-carbon of the hydrazone. This reactivity under nonbasic conditions was totally unprecedented, and it had not been observed previously in the literature for enolizable hydrazones since the use of a strong base was always required via enamine formation and subsequently trapped by electrophiles.[47] To explain this surprising reactivity we suggested that the 
hydrazones 16 should be in equilibrium with its ene-hydrazine form 19, which would furnish the observed adducts by attacking the activated nitroalkene as represented in Scheme 8. Even when the presence of 19 could not be detected by NMR experiments, because the equilibrium is shifted to the more favorable hydrazone form 16, the small amount of $\mathbf{1 9}$ in the medium was enough to allow the reaction and to move the equilibrium towards the appropriate direction.

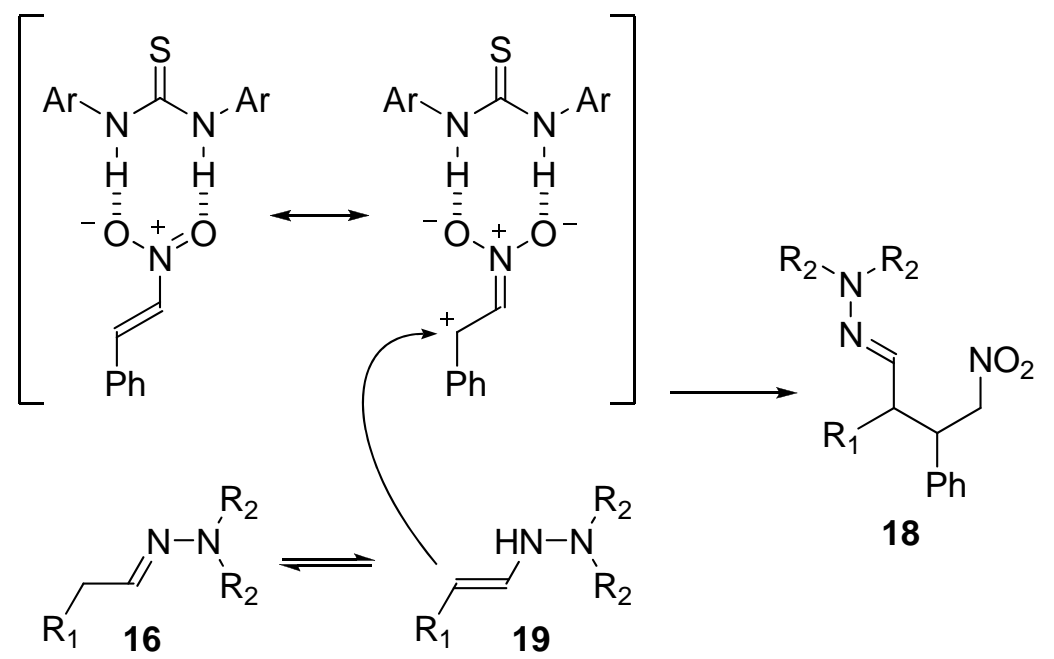

Scheme 8 Proposed mechanism via hydrazone-ene-hydrazine equilibrium

We have illustrated a novel example of reactivity for thiourea 4 promoting an unprecedented conjugate addition of enolizable hydrazones to nitroalkenes, reacting at the $\alpha$-carbon in absence of base and affording $\gamma$-nitrohydrazones in very good yields. This kind of reactivity is still open to be studied from an enantioselective point of view.

\subsubsection{Michael addition reaction of formaldehyde $N, N$-dialkylhydrazones to $\beta, \gamma$-unsaturated $\alpha$-keto} esters

Among the different Michael addition approaches, the nucleophilic reactivity of formaldehyde dialkylhydrazones seems to be too low for reactions using weak electrophiles, such as $\alpha, \beta$-unsaturated carbonyl compounds, and therefore, hydrazones have been rarely considered as formyl anion equivalents of synthetic value against these substrates.[48] Encouraged for the lack of catalytic examples and in order to contribute to this less explored field, we studied the viability of thiourea catalyzed Michael addition reaction of hydrazone 20 and $\beta, \gamma$-unsaturated $\alpha$-ketoester 21 (Scheme 9).[49] After testing different parameters such as chiral catalysts, solvents, the dilution and temperature, we finally explored the scope of this new umpolung strategy with $\beta, \gamma$-unsaturated $\alpha$-ketoester derivatives 21 and furnishing the corresponding adducts 22a-f in suitable yields and good enantioselectivities at -40 or $-60{ }^{\circ} \mathrm{C}$ (Scheme 9). In this process, thiourea 7d was once more identified as the more promising catalyst for promoting this Michael addition. 


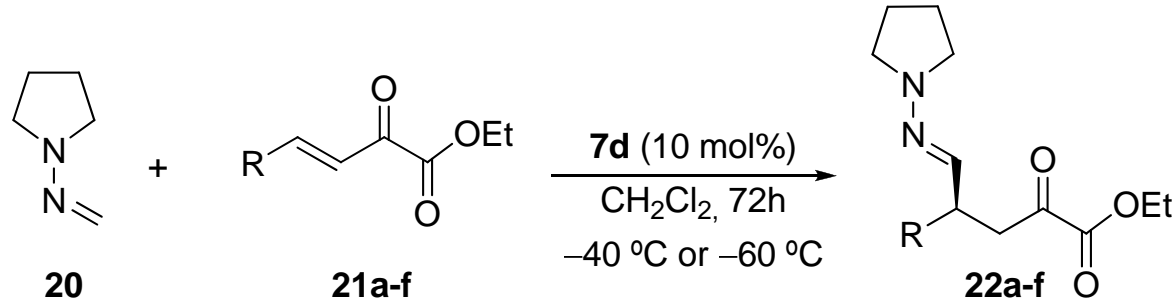<smiles>CCOC(=O)C(=O)CC(C)C=NN1CCCC1</smiles>

$22 a$

yield $60 \%$ ee $80 \%$<smiles>CCCCC(CC(=O)C(=O)OCC)[C@H](C)N=NN1CCCC1</smiles>

22d

yield $61 \%$ ee $70 \%$<smiles>CCOC(=O)C(=O)C[C@H](/C=N/N1CCCC1)CC(C)C</smiles>

22b

yield $80 \%$ ee $78 \%$<smiles>CCOC(=O)C(=O)C[C@H](/C=N/N1CCCC1)CC(C)(C)C</smiles>

$22 \mathrm{e}$ yield $64 \%$ ee $58 \%$<smiles>CCOC(=O)C(=O)C[C@H](/C=N/N1CCCC1)C(C)CC</smiles>

22c yield $75 \%$ ee $78 \%$<smiles>CCOC(=O)C(=O)C[C@@H](/C=N/N1CCCC1)C1CCCCC1</smiles>

$22 f$

yield $82 \%$ ee $72 \%$

Scheme 9 Organocatalytic Michael addition reaction using hydrazone pyrrolodine derivative 20

The synthetic importance of these substrates lays in the possibility of further cleavage of the hydrazone moiety for regenerating the carbonyl function under a range of mild conditions, and the later transformation of final products into useful chiral building blocks. In this regard, the utility of adducts 22 was established by transforming the hydrazone group into some target compounds such as the corresponding nitriles 23a,b by oxidative cleavage and into the succinate 24 resulting from oxidative decarboxylation of an unstable intermediate in situ generated under the specified conditions as described in Scheme 10. The latter allowed the assignment of the absolute configuration of product 22a as $R$, and the same configuration was assumed for adducts $\mathbf{2 2 b - f}$ by analogy. 


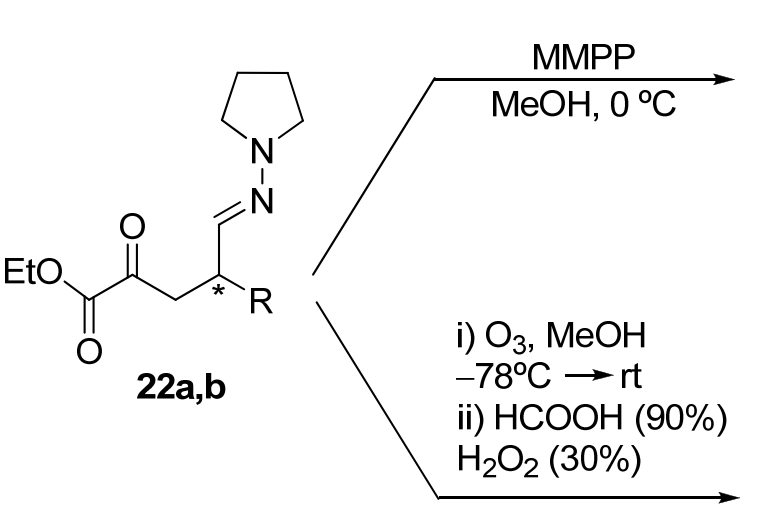

iii) $\mathrm{SOCl}_{2}$

$\mathrm{MeOH}$<smiles>[R]C(C#N)CC(=O)C(=O)OCC</smiles>

R: Me (23a) $53 \%$ yield

$\mathrm{R}: i-\operatorname{Pr}(23 \mathrm{~b}) 56 \%$ yield<smiles>COC(=O)CC(C)C(=O)OC</smiles>

24

$56 \%$ yield

Scheme 10 Syntheses of target compounds

In order to explain the absolute configuration obtained in the final products, we envisioned that catalyst $\mathbf{7 d}$ would also act in a bifunctional way as previously mentioned in Figure 7.[29] Therefore, whereas the two thiourea hydrogen atoms would activate the carbonyl group, the free alcoholic function would interact with the hydrazone with a weak hydrogen bond, directing the attack of the incoming nucleophile on the $R e$ face of the $\beta, \gamma$-unsaturated $\alpha$-ketoester as illustrated in Figure 9.

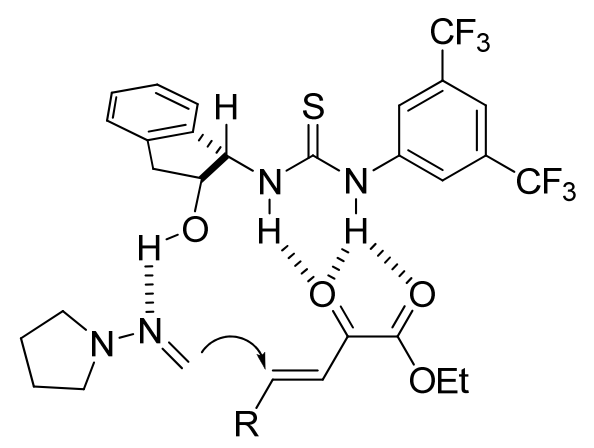

Figure 9 Possible bifunctional mode of action

This synthetically useful class of hydrazones, from formaldehyde $N, N$-dialkylhydrazones or from enolizable aldehydes, represents an interesting type of umpolung carbonyl reagent or imine surrogates, respectively. Moreover, their neutral character as electrophiles or nucleophiles makes them compatible with many functional groups, being potential substrates in many catalytic approaches. Therefore, we expect that further efforts will be dedicated to the development of new applications based on the combination of organocatalysis and $N, N$-dialkylhydrazones, and a novel but promising area of research could grow up around these compounds.

\subsubsection{Hydrophosphonylation reaction of nitroalkenes}

Currently the stereoselective synthesis of $\alpha$-[50] and $\beta$-aminophosphonic[51] acids and derivatives has attracted a particular interest due to their appealing biological activities as structurally analogues to $\alpha$ - and $\beta$ amino acids respectively, and because in general phosphorus compounds are important substrates in biochemical processes (Figure 10). 
<smiles>CC(C)CC(NC(CN1C(=O)c2cccc3cccc(c23)C1=O)C(=O)O)C(=O)NC(C(N)=O)c1ccccc1</smiles><smiles>Nc1nc2c(ncn2CCP(=O)(O)O)c(=O)[nH]1</smiles>

Human purine nucleoside phosphorilase inhibitor<smiles>NC(O)CP(=O)(O)O</smiles>

Glutamate receptor antagonist

Figure 10 Biologically active $\beta$-amino phosphoric acid derivatives

However, although great progresses have been accomplished in the preparation of enantioenriched $\alpha$ aminophosphonates,[50,52] the strategies for the access to $\beta$-aminophosphonic acids have been less explored,[51] and only a few examples based in organocatalytic protocols have been reported.[53] The Michael addition of phosphorus compounds to nitroalkenes[54,55] has been applied as an effective tool for the straightforward synthesis of P-C bonds, becoming a convenient method for the construction of functionalized $\beta$-aminophosphonates. In this respect, only three interesting and versatile methods concerning the organocatalytic conjugate addition of diphenyl phosphite to nitroalkenes have been reported using chiral guanidine 25, [53a] quinine 26[53b] and squaramide 27[53c] (Figure 11). Therefore, the development of new catalytic methodologies to provide $\beta$-nitrophosphonates is still of notable importance.<smiles>CC(C)(C)c1cc(C(C)(C)C)cc(C(C)(C)C)c1</smiles><smiles>C=CC1CN2CCC1C2[C@H](O)c1ccnc2ccc(OC)cc12</smiles><smiles>O=c1c(Nc2ccc(C(F)(F)F)cc2)c(N[C@@H]2CCCCC2N2CCCCC2)c1=O</smiles>

yield $66-99 \%$ ee $95-99 \%$

Figure 11 Efficient catalysts for the synthesis of $\beta$-nitrophosphonates

Recently we explored this process using chiral thiourea catalysts as a new viable route to obtain the desired $\beta$-aminophosphonate adducts.[56] Among all the thioureas tested in a preliminary study to obtain the more efficient catalyst (Figure 12), only $\mathbf{3 1}$ afforded promising results in terms of both reactivity and enantioselectivity. It is noteworthy that with all catalysts shown in Figure 12 the addition of an external base $\left(\mathrm{Pr}_{2} \mathrm{EtN}\right)$ was always required in order to achieve reactivity in the explored reaction, except when using thiourea 31 which also has a Brønsted base moiety in its structure. 
<smiles>[R]C1Cc2ccccc2C1NC(=S)Nc1cc(C(F)(F)F)cc(C(F)(F)F)c1</smiles><smiles>OC1Cc2ccccc2C1NC(=S)Nc1cc2ccccc2c2ccccc12</smiles><smiles>[R]NC(=O)C([13CH3])NC(N)=S</smiles><smiles>C=NC1CCCCC1NO</smiles>

28a $R^{1}=M e, R^{2}=B n$, $R^{3}=H, R^{4}=t B u$

$28 b R^{1}=R^{2}=M e$,

$\mathrm{R}^{3}=t \mathrm{BuCOO}, \mathrm{R}^{4}=\mathrm{H}$<smiles>Cc1ccc(-c2ccccc2)n1C1CCCCC1NC(=S)N[C@H](C(=O)N(CC(C)C)CC(C)C)C(C)(C)C</smiles>

Figure 12 Thiourea catalysts tested

After an exhaustive exploration of different parameters such as solvents, various dialkylphosphites, temperature and reagent concentration, the best reaction conditions were accomplished with bifunctional thiourea 31 using $\mathrm{CH}_{2} \mathrm{Cl}_{2}$ and $10 \mathrm{~mol} \%$ of catalyst at $-10{ }^{\circ} \mathrm{C}$, and we extended the applicability of our developed procedure to a variety of aromatic and aliphatic nitroalkenes (Scheme 11). 


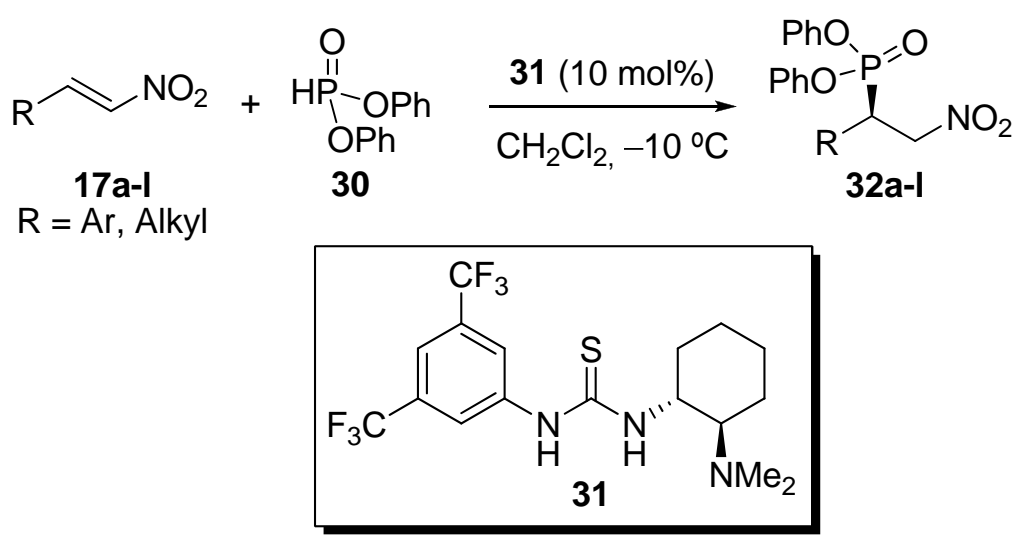<smiles>O=[N+]([O-])CC(c1ccccc1)[P+](=O)([O-])OP</smiles>

$32 a$

yield $95 \%$

ee $76 \%$<smiles>O=[N+]([O-])CC(c1ccccc1C(F)(F)F)P(=O)(O)Oc1ccccc1</smiles>

$32 \mathrm{e}$

yield $79 \%$

ee $76 \%$<smiles>CC(C)(C)Oc1ccc([C@@H](C(C[P+](=O)[O-])[N+](=O)[O-])P(=O)(O)Oc2ccccc2)cc1</smiles>

32i

yield $81 \%$

ee $78 \%$<smiles>Cc1ccc(C(C[N+](=O)[O-])P(=O)(O)Oc2ccccc2)cc1</smiles>

32b

yield $81 \%$

ee $74 \%$<smiles>O=[N+]([O-])CC(c1ccc(Cl)cc1)P(=O)(Oc1ccccc1)P(=O)(O)c1ccccc1</smiles>

$32 f$

yield $87 \%$

ee $73 \%$<smiles>O=[N+]([O-])CC(c1ccco1)[P+](=O)(O)Oc1ccccc1</smiles>

32j

yield $67 \%$

ee $76 \%$<smiles>COc1ccc(C(C[N+](=O)[O-])P(=O)(O)Oc2ccccc2)cc1</smiles>

32c

yield $79 \%$

ee $78 \%$<smiles>O=[N+]([O-])CC(c1ccc(F)cc1)P(=O)(O)Oc1ccccc1</smiles>

$32 \mathrm{~g}$

yield $60 \%$

ee $72 \%$<smiles>O=[N+]([O-])CC(C1CCCCC1)P(=O)(Oc1ccccc1)OP(=O)([O-])O</smiles>

32k<smiles>COc1ccccc1C(C[N+](=O)[O-])P(=O)(O)Oc1ccccc1</smiles>

32d

yield $75 \%$

ee $73 \%$<smiles>O=[N+]([O-])CC(c1ccc(Br)cc1)P(=O)(O)P(=O)(O)c1ccccc1</smiles>

32h

yield $79 \%$ ee $76 \%$<smiles>O=[N+]([O-])CC(CCc1ccccc1)P(=O)(O)Oc1ccccc1</smiles>

321

yield $60 \%$ ee $68 \%$

Scheme 11 Thiourea catalyzed organocatalytic hydrophosphonylation of nitroalkenes

Our moderate results are comparable to those previously reported by Wang and co-workers,[53a] but in shorter reaction times because in our case it was not necessary to decrease the temperature to $-55{ }^{\circ} \mathrm{C}$. However, we could not improve the excellent results reported by Terada's[53b] and Rawal's[53c] groups. Nevertheless, the accessibility to the commercially available thiourea 31, support the simplicity and viability of our methodology. The absolute configuration of the Michael adducts 32a-l was determined by comparison between the optical rotation values with those previously reported in the literature for the same products.[53] On the basis of the experimental results and comparing with other thioureas tested in our study, we envisioned that catalyst $\mathbf{3 1}$ could act following a bifunctional model as previously proposed in the literature 
for the same structure.[57] In order to give additional support to this hypothesis we performed computational calculations using a DFT model: B3LYP/6-31+G*.[58] We have studied different approaches and the more stable TS-1 is in agreement with the experimental results, since it would afford the observed enantiomer in our final adducts (Figure 13).

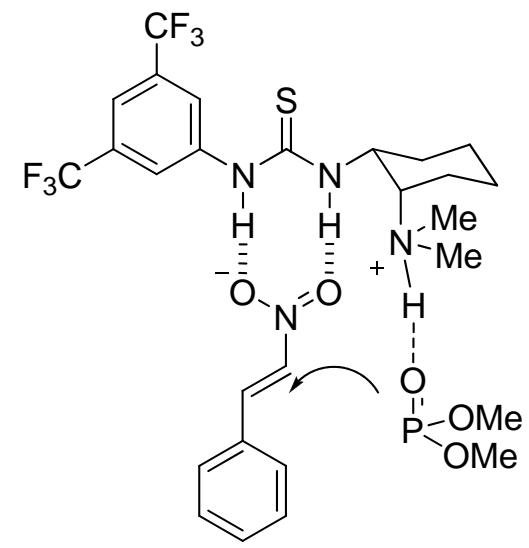

TS-1

$0.00 \mathrm{kcal} / \mathrm{mol}$ Re attack

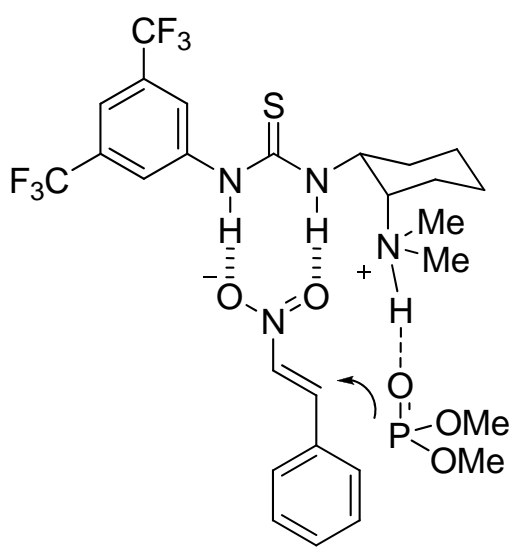

TS-2

$1.39 \mathrm{Kcal} / \mathrm{mol}$ Si attack

Figure 13 DFT calculations at B3LYP/6-31+G* level. Proposed transition state models

Even when this field has recently emerged, the growing interest for $\beta$-aminophosphonic acids showing biological activity or as useful intermediates for the preparation of peptidomimetic derivatives should stimulate further searches and provide achievements in this area.

\subsection{Aza-Henry reaction}

The addition of nitroalkanes to $\mathrm{C}=\mathrm{N}$ bond (aza-Henry or nitro-Mannich reaction)[59] is an important synthetic procedure that affords $\mathrm{C}-\mathrm{C}$ bond formation, and represents a simple route to achieve two different vicinal nitrogenated functionalities. The resulting $\beta$-nitroamine could be further transformed into a variety of valuable building blocks and interesting biological compounds such as 1,2-diamines[60] or $\alpha$-amino acids.[61] Much attention has been paid to the catalytic asymmetric version of this reaction over the years, [59,62] but the search of new effective catalysts to promote highly selective processes is still remaining.

In this area we focused our research on the study of modified cinchona alkaloids[32,63] in order to explore the capability of these structures to promote the addition of nitromethane to a variety of protected aromatic and heteroaromatic imines (Scheme 12).[64] In a preliminary screening of a variety of catalysts (Figure 14), cinchona-based thiourea organocatalyst $\mathbf{4 3}$ proved to be the most efficient one. 
<smiles>C=CC1CC2CCN1C2[C@H](OC(C)=O)c1ccnc2ccc(OC)cc12</smiles>

33<smiles>C=CC1CC2CCN1CC2[C@H](O)c1ccnc2ccc(OC)cc12</smiles>

37<smiles>C=CC1CC2CCN1C2[C@H](NC(=O)c1ccccc1)c1ccnc2ccc(OC)cc12</smiles>

34<smiles>CCC12CCC(CC1c1ccnc3ccc(O)cc13)N1CCC2C1</smiles>

35<smiles>C=CC1CC2CCN1CC2[C@H](O)c1ccnc2ccc(OC)cc12</smiles>

36<smiles>C=CC1CC2CCN1CC2[C@H](OC(=O)Nc1cc(C(F)(F)F)cc(C(F)(F)F)c1)c1ccnc2ccc(OC)cc12</smiles>

38<smiles>C=CC1CC2CCN1C([C@H](NC(=S)Nc1cc(C(F)(F)F)cc(C(F)(F)F)c1)c1ccnc3ccc(OC)cc13)C2</smiles>

39

Figure 14 Representative cinchona alkaloids screened in the aza-Henry reaction 


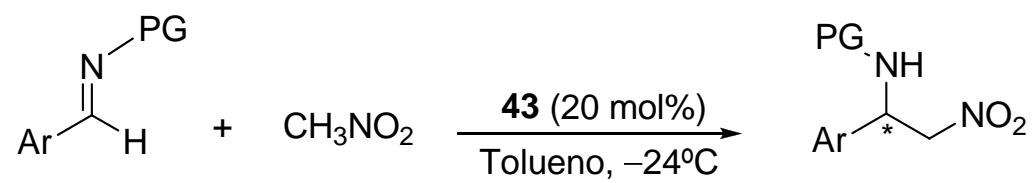

PG: Boc (40),

44a-h,45a,b,46

Cbz (41), Fmoc (42)

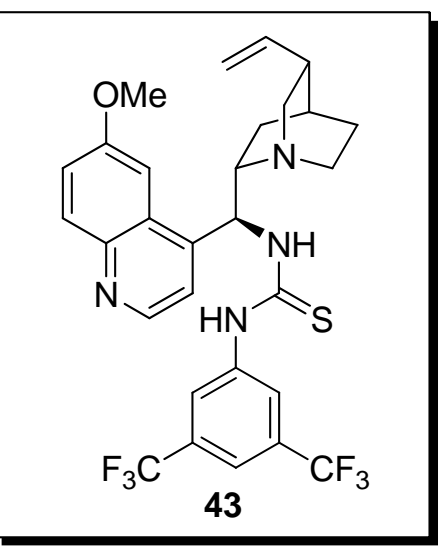<smiles>CC(C)(C)OC(=O)NC(C[N+](=O)[O-])c1ccccc1</smiles>

$44 a$

$72 \%$ yield

$88 \%$ ee<smiles>O=C(NC(C[N+](=O)[O-])c1ccccc1)c1ccccc1</smiles>

$45 a$ $64 \%$ yield $84 \%$ ee<smiles>CCCNC(C[N+](=O)[O-])c1ccccc1</smiles>

46

$60 \%$ yield $90 \%$ ee<smiles>CC(C)(C)OC(=O)NC(C[N+](=O)[O-])c1ccc(Cl)cc1</smiles><smiles>O=C(Cc1ccccc1)NC(C[N+](=O)[O-])c1ccc(Cl)cc1</smiles><smiles>CC(C)(C)OC(=O)N[C@H](C[N+](=O)[O-])c1cccc2ccccc12</smiles><smiles>CC(C)(C)OC(=O)N[C@H](CN=O)c1ccc2ccccc2c1</smiles><smiles>CC(C)(C)OC(=O)NC(C[N+](=O)[O-])c1ccccc1Br</smiles>

44e $66 \%$ yield $80 \%$ ee<smiles>COc1ccc(C(C[N+](=O)[O-])NC(=O)OC(C)(C)C)cc1</smiles>

$44 f$ $65 \%$ yield $82 \%$ ee<smiles>CC(C)(C)OC(=O)NC(C[N+](=O)[O-])c1cccs1</smiles>

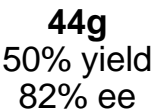<smiles>CC(C)(C)OC(=O)NC(C[N+](=O)[O-])c1ccco1</smiles>

44h

$70 \%$ yield $44 \%$ ee

Scheme 12 Organocatalytic aza-Henry reaction using cinchona-based thiourea 43

The final adducts were isolated in moderate to good yields and high levels of enantioselectivity (up to 94\%). Moreover, several protecting groups on the nitrogen atom were tested, including $\mathrm{N}$-Boc, $\mathrm{N}$-Cbz and $\mathrm{N}$-Fmoc groups, and although the best results were obtained with $N$-Boc group, the high values achieved with the other two protecting groups confirmed the wide range of tolerance of this process to different $N$-carbamoyl groups and imines. Although mechanistic explanation was not given, we cannot rule out a possible bifunctional mode of action by the catalyst activating the reaction through the thiourea moiety and with the 
quinuclidinic base function as previously suggested for this catalyst.[65] However we observed that catalysts with the $\mathrm{OH}$ group of quinine derivative protected via acetylation or carbamate formation, as derivatives $\mathbf{3 3}$ and $\mathbf{3 8}$, or replaced by a benzomido moiety as in $\mathbf{3 4}$, afforded the formation of the desired adducts with very poor yields. This fact supports the importance of the presence of the thiourea moiety in the backbone of the catalyst.

The products resulting from these strategies are very important motifs in biologically active compounds and in medicinal chemistry, for this reason this area of research has encouraged significant efforts in order to improve the previous published results, however several drawbacks have not been overcome yet, and this fact will prompt further investigations in this field.

\section{Conclusions}

In this chapter our small contribution in the huge field of organocatalysis in general and chiral thioureas in particular is reported. Different thiourea catalyzed processes have been illustrated, some of them original and pioneering in this area, which became a precedent for further explored reactions. Nevertheless, the exciting organocatalytic world is still in expansion and it is addressed to the development of new catalysts and more complex systems. We attend every day to the discovery of new amazing approaches and efficient catalysts, among them, thiourea catalysts still represent an interesting research area. In the next years improved and valuable catalysts will be reported and more complex versions of these and other useful processes will emerge. In fact, the searching for environmentally friendly catalysts is nowadays a challenge and one of the main goal in the scientific world, however its accomplishment will require further investigations.

\section{Acknowledgments}

We would like to thank the research groups where all these projects have been performed and reached: Prof. Ricci's group (Bologna, Italy, 2003-2006), Prof. Lassaletta and Prof. Fernández's group (Seville, Spain, 2006-2007) and Prof. Merino and Prof. Tejero's group (Zaragoza, Spain, 2008-present). We want to thank the Spanish Ministry of Science and Innovation (MICINN. Madrid, Spain. Project CTQ2009-09028 and CTQ2010-19606), FEDER Program and the Government of Aragon (Zaragoza, Spain. Project PI064/09 and Research Group E-10) for their financial support of our research. E. M.-L. thanks CSIC for a JAE-Doc postdoctoral contract. R.P.H. thanks the ARAID Foundation for a permanent position.

\section{References}

1 (a) Pellissier, H. (ed) (2010) Recent Developments in Asymmetric Organocatalysis, RSC Publishing, Cambridge. (b) Berkessel, A. and Groger, H. (2005) in Asymmetric Organocatalysis, Wiley-VCH, Weinheim. (c) Dalko, P. I. (ed) (2007) Enantioselective Organocatalysis, Wiley-VCH, Weinheim. (d) List, B. (ed) (2010) Asymmetric Organocatalysis. Top. Curr.Chem., 291, Springer, Heidelberg.

2 (a) de Figueiredo R. M. and Christmann, M. (2007) Organocatalytic synthesis of drugs and bioactive natural products. Eur. J. Org. Chem., 2575-2600. (b) Marqués-López, E., Herrera, R. P. and Christmann, M. (2010) Asymmetric organocatalysis in total synthesis - a trial by fire. Nat. Prod. Rep., 27, 1138-1167. 
3 Dalko, P. I. and Mosan, L. (2004) In the golden age of organocatalysis. Angew. Chem. Int. Ed., 43, 51385175.

4 (a) Pihko, P. M., Majander, I. and Erkkilä, A. (2010) Enamine catalysis. Top. Curr. Chem. 291, 29-75. (b)

Brazier, J. B. and Tomkinson, N. C. O. (2010) Secondary and primary amine catalysts for iminium catalysis. Top. Curr. Chem. 291, 281-347.

5 (a) Berkessel, A. (2008) Organocatalysis by hydrogen bonding networks in Organocatalysis, (eds M. T. Reetz, B. List, H. Jaroch and H. Weinmann), Springer-Verlag Berlin Heidelberg, Vol 2, pp. 281-297. (b) Pihko, P. M. (ed) (2009) Hydrogen bonding in organic synthesis, Wiley-VCH, Weinheim. (c) Kerstin, E.-E. and Berkessel, A. (2010) Noncovalent organocatalysis based on hydrogen bonding: elucidation of reaction paths by computational methods. Top. Curr. Chem. 291, 1-27.

6 (a) Ooi, T. and Maruoka, K. (2007) Recent advances in asymmetric phase-transfer catalysis. Angew. Chem. Int. Ed., 46, 4222-4266. (b) Hashimoto, T. and Maruoka, K. (2007) Recent development and application of chiral phase-transfer catalysts. Chem. Rev., 107, 5656-5682. (c) Maruoka, K. (ed) (2008) Asymmetric Phase Transfer Catalysis, Wiley-VCH, Weinheim.

7 Engeldinger, E., Armspach, D. and Matt, D. (2003) Capped cyclodextrins. Chem. Rev., 103, 4147-4174.

8 (a) Schreiner, P. R. (2003) Metal-free organocatalysis through explicit hydrogen bonding interactions. Chem. Soc. Rev., 32, 289-296. (b) Takemoto, Y. (2005) Recognition and activation by ureas and thioureas: stereoselective reactions using ureas and thioureas as hydrogen-bonding donors. Org. Biomol. Chem., 3, 4299-4306. (c) Connon, S. J. (2006) Organocatalysis mediated by (thio)urea derivatives. Chem. Eur. J., 12, 5418-5427. (d) Taylor, M. S. and Jacobsen, E. N. (2006) Asymmetric catalysis by chiral hydrogen-bond donors. Angew. Chem. Int. Ed., 45, 1520-1543. (e) Doyle, A. G. and Jacobsen, E. N. (2007) Small-molecules H-bond donors in asymmetric catalysis. Chem. Rev., 107, 5713-5743. (f) Miyabe, H. and Takemoto, Y. (2008) Discovery and Application of asymmetric reaction by multi-functional thioureas. Bull. Chem. Soc. Jpn., 81, 785-795. (g) Zhang, Z. and Schreiner, P. R. (2009) (Thio)urea organocatalysis - What can be learnt from anion recognition?. Chem. Soc. Rev., 38, 1187-1198. (h) Marqués-López, E. and Herrera, R. P. (2009) El renacer de un Nuevo campo: la organocatálisis asimetrica. Tioureas como organocatalizadores. An. Quím., 105, 5-12.

9 (a) Ishikawa, T. and Kumamoto, T. (2006) Guanidines in organic synthesis. Synthesis, 737-752. (b) Leow, D. and Tan, C.-H. (2010) Catalytic reactions of chiral guanidines and guanidinium salts. Synlett, 1589-1605. 10 (a) Huang, Y., Unni, A. K., Thadani, A. N. and Rawal, V. H. (2003) Single enantiomers from a chiralalcohol catalyst. Nature, 424, 146-146. (b) Thadani, A. N., Stankovic, A. R. and Rawal, V. H. (2004) Enantioselective Diels-Alder reactions catalyzed by hydrogen bonding. Proc. Natl. Acad. Sci. USA, 101, 5846-5850.

11 (a) McDougal, N. T. and Schaus, S. E. (2003) Asymmetric Morita-Baylis-Hillman reactions catalyzed by chiral Brønsted acids. J. Am. Chem. Soc., 125, 12094-12095. (b) McDougal, N. T., Trevellini, W. L., Rodgen, S. A., Kliman, L. T. and Schaus, S. E. (2004) The development of the asymmetric Morita-Baylis- 
Hillman reaction catalyzed by chiral Brønsted acids. Adv. Synth. Catal., 346, 1231-1240. (c) Takizawa, S., Horii, A. and Sasai, H. (2010) Acid-base organocatalysts for the aza-Morita-Baylis-Hilmann reaction of nitroalkenes. Tetrahedron: Asymmetry, 21, 891-894.

12 (a) Nugent, B. M., Yoder, R. A. and Johnston, J. N. (2004) Chiral proton catalysis: a catalytic enantioselective direct aza-Henry reaction. J. Am. Chem. Soc., 126, 3418-3419. (b) Hess, A. S., Yoder, R. A. and Johnston, J. N. (2006) Chiral proton catalysis: $\mathrm{pK}_{\mathrm{a}}$ determination for a BAM-HX Brønsted acid. Synlett, 147-149. (c) Singh, A., Yoder, R. A., Shen, B. and Johnston, J. N. (2007) Chiral proton catalysis: enantioselective Brønsted acid catalysed additions of nitroacetic acid derivatives as glycine equivalents. $J$. Am. Chem. Soc., 129, 3466-3467. (d) Shen, B. and Johnston, J. N. (2008) A formal enantioselective acetate Mannich reaction: the nitro functional group as a traceless agent for the activation and enantiocontrol in the synthesis of $\beta$-amino acids. Org. Lett., 10, 4397-4400.

13 (a) Connon, S. J. (2006) Chiral phosphoric acids: powerful organocatalysts for asymmetric addition reactions to imines. Angew. Chem. Int. Ed., 45, 3909-3912. (b) Akiyama, T. (2007) Stronger Brønsted acids. Chem. Rev., 107, 5744-5758. (c) Adair, G., Mukherjee, S. and List, B. (2008) TRIP-A powerful Brønsted acid catalyst for asymmetric synthesis. Aldrichimica Acta, 41, 31-39. (d) Terada, M. (2008) Binaphtholderived phosphoric acid as a versatile catalyst for enantioselective carbon-carbon bond forming reactions. Chem. Commun., 4097-4112. (e) Terada, M. (2010) Chiral phosphoric acids as versatile catalysts for enantioselective transformation. Synthesis, 1929-1982. (f) Terada, M. (2010) Chiral phosphoric acids as versatile catalysts for enantioselective carbon-carbon forming reactions. Bull. Chem. Soc. Jpn., 83, 101-119.

14 (a) Etter, M. C. and Panunto, T. W. (1988) 1,3-Bis(m-nitrophenyl)urea: an exceptionally good complexing agent for proton acceptors. J. Am. Chem. Soc., 110, 5896-5897. (b) Etter, M. C., UrbañczykLipkowska, Z., Zia-Ebrahimi, M. and Panunto, T. W. (1990) Hydrogen-bond direct cocrystallization and molecular recognition properties of diarylureas. J. Am. Chem. Soc., 112, 8415-8426. (c) Kelly, T. R. and Kim, M. H. (1994) Relative binding affinity of carboxylate and its isosteres: nitro, phosphate, phosphonate, sulfonate, and $\gamma$-lactone. J. Am. Chem. Soc., 116, 7072-7080.

15 Curran, D. P. and Kuo, L. H. (1994) Altering the stereochemistry of allylation reactions of cyclic $\alpha$ sulfinyl radicals with diarylureas. J. Org. Chem., 59, 3259-3261.

16 Curran, D. P. and Kuo, L. H. (1995) Acceleration of a dipolar Claisen rearrangement by hydrogen bonding to a soluble diaryl urea. Tetrahedron Lett., 36, 6647-6650.

17 Hine, J., Linden, S.-M. and Kanagasabapathy, V. M. (1985) 1,8-Biphenylenediol is a double-hydrogenbonding catalyst for reaction of an epoxide with a nucleophile. J. Am. Chem. Soc., 107, 1083-1984.

18 Kelly, T. R.; Meghani, P. and Ekkundi, V. S. (1990) Diels-Alder reactions: rate acceleration promoted by a biphenylenediol. Tetrahedron Lett., 31, 3381-3384.

19 (a) Bandini, M., Melloni, A. and Umani-Ronchi, A. (2004) New catalytic approaches in the stereoselective Friedel-Crafts alkylation reaction. Angew. Chem. Int. Ed., 43, 550-556. (b) Bandini, M., Melloni, A., Tommasi, S. and Umani-Ronchi, A. (2005) A journey across recent advances in catalytic and 
stereoselective alkylation of indoles. Synlett, 1199-1222. (d) Bandini, M. and Umani-Ronchi, A. (eds) (2009) Catalytic Asymmetric Friedel-Crafts Alkylations, Wiley-VCH, Weinheim.

20 (a) Marqués-López, E., Diez-Martinez, A., Merino, P. and Herrera, R. P. (2009) The role of the indole in important organocatalytic enantioselective Friedel-Crafts alkylation reactions. Curr. Org. Chem., 13, 15851609. (b) Terrasson, V., de Figueiredo, R. M. and Campagne, J. M. (2010) Organocatalyzed asymmetric Friedel-Crafts reactions. Eur. J. Org. Chem., 2635-2655.

21 (a) Borschberg, H.-J. (2005) New strategies for the synthesis of monoterpene indole alkaloids. Curr. Org. Chem., 9, 1465-1491. (b) Cacchi, S. and Fabrizi, G. (2005) Synthesis and functionalization of indoles through palladiumcatalyzed reactions. Chem. Rev., 105, 2873-2920. (c) Poulsen, T. B. and Jørgensen, K. A. (2008) Catalytic asymmetric Friedel-Crafts alkylation reactions-copper showed the way. Chem. Rev., 108, 2903-2915.

22 Dessole, G., Herrera, R. P. and Ricci, A. (2004) H-bonding organocatalysed Friedel-Crats alkylation of aromatic and heteroatomatic systems with nitroolefines. Synlett, 2374-2378.

23 Harrington, P. E. and Kerr, M. A. (1996) Reaction of indoles with electron deficient olefins catalyzed by $\mathrm{Yb}(\mathrm{OTf})_{3} \cdot 3 \mathrm{H}_{2} \mathrm{O}$. Synlett, 1047-1048.

24 Komoto, I. and Kobayashi, S. (2002) 1-Dodecyloxy-4-perfluoroalkylbenzene as a novel efficient addtivie in aldol reactions and Friedel-Crafts alkylation in supercritical carbon dioxide. Org. Lett., 4, 1115-1118.

25 Alam, M. M., Varala, R. and Adapa, S. R. (2003) Conjugate addition of indoles and thiols with electrondeficient olefins catalyzed by $\mathrm{Bi}(\mathrm{OTf})_{3}$. Tetrahedron Lett., 44, 5115-5119.

26 Bandini, M., Melchiorre, P., Melloni, A. and Umani-Ronchi, A. (2002) A practical indium tribromide catalysed addition of indoles to nitroalkenes in aqueous media. Synthesis, 1110-1114.

27 Bordwell, F. G., Algrim, D. J. and Harrelson, J. A. Jr. (1988) The relative ease of removing a proton, a hydrogen atom, or an electron from carboxamides versus thiocarboxamides. J. Am.Chem. Soc., 110, 59035904.

28 Scheerder, J., Engbersen, J. F. J., Casnati, A., Ungaro, R. and Reinhoudt, D. N. (1995) Complexation of halide anions and tricarboxylate anions by neutral urea-derivatized p-tert-butylcalix[6]arenes. J. Org. Chem., 60, 6448-6454.

29 Herrera, R. P., Sgarzani, V., Bernardi, L. and Ricci, A. (2005) Catalytic enantioselective Friedel-Crafts alkylation of indoles with nitroalkenes by using a simple thiourea organocatalyst. Angew. Chem. Int. Ed., 44, 6576-6579.

30 Freeman, S. and Alder, J. F. (2002) Arylethylamine psychotropic recreational drugs: a chemical perspective. Eur. J. Med. Chem., 37, 527-539.

31 Oh, S. J., Ha, H.-J., Chi, D. Y. and Lee, H. K. (2001) Serotonin receptor and transporter ligands-current status. Curr. Med. Chem., 8, 999-1034.

32 Connon, S. J. (2008) Asymmetric catalysis with bifunctional cinchona alkaloid-based urea and thiourea organocatalysts. Chem. Commun., 2499-2510. 
33 Zhuang, W., Hazell, R. G. and Jørgensen, K. A. (2005) Enantioselective Friedel-Crafts type addition of indoles to nitro-olefins using a chiral hydrogen-bonding catalyst-synthesis of optically active tetrahydro- $\beta$ carbolines. Org. Biomol. Chem., 3, 2566-2571.

34 Fleming, E. M., McCabe, T. and Connon, S. J. (2006) Novel axially chiral bis-arylthiourea-based organocatalysts for asymmetric Friedel-Crafts type reactions. Tetrahedron Lett., 47, 7037-7042.

35 Ganesh, M. and Seidel, D. (2008) Catalytic enantioselective additions of indoles to nitroalkenes. J. Am. Chem. Soc., 130, 16464-16465.

36 Itoh, J., Fuchibe, K. and Akiyama, T. (2008) Chiral phosphoric acid catalyzed enantioselective FriedelCrafts alkylation of indoles with nitroalkenes: cooperative effect of $3 \AA$ molecular sieves. Angew. Chem. Int. Ed., 47, 4016-4018.

37 Roca-Lopez, D., Sadaba, D., Delso, I., Herrera, R. P., Tejero, T. and Merino, P. (2010) Asymmetric organocatalytic synthesis of $\gamma$-nitrocarbonyl compounds through Michael and domino reactions. Tetrahedron: Asymmetry, 21, 2561-2601.

38 (a) Vicario, J. L., Badia, D. and Carrillo, L. (2007) Organocatalytic enantioselective Michael and heteroMichael reactions. Synthesis, 2065-2092. (b) Tsogoeva, S. B. (2007) Recent advances in asymmetric organocatalytic 1,4-conjugate addition. Eur. J. Org. Chem., 1701-1716. (b) Almaşi, D., Alonso, D. A. and Nájera, C. (2007) Organocatalytic asymmetric conjugate addition. Tetrahedron: Asymmetry, 18, 299-365.

39 (a) Enders, D., Wang, C. and Liebich, J. X. (2009) Organocatalytic asymmetric aza-Michael additions. Chem. Eur. J., 15, 11058-11076. (b) Krishna, P. R., Sreeshailam, A. and Srinivas, R. (2009) Recent advances and applications in asymmetric aza-Michael addition chemistry. Tetrahedron, 65, 9657-9572.

40 Guo, H.-C. and Ma, J.-A. (2006) Catalytic asymmetric tandem transformations triggered by conjugate additions. Angew. Chem. Int. Ed., 45, 354-366.

41 Fernández, R. and Lassaletta, J. M (2000) Formaldehyde N,N-dialkylhydrazones as C-1 building-blocks in asymmetric synthesis. Synlett, 1228-1240.

42 (a) Marqués-López, E., Herrera, R. P., Fernández, R. and Lassaletta, J. M. (2008) Uncatalyzed Streckertype reaction of $N, N$-dialkylhydrazones in pure water. Eur. J. Org. Chem., 3457-3460. (b) Lazny, R. and Nodzewska, A. (2010) $N, N$-dialkylhydrazones in organic synthesis. From simple $N, N$-dimethylhydrazones to supported chiral auxiliaries. Chem. Rev., 110, 1386-1434.

43 Sugiura, M. and Kobayashi, S. (2005) N-Acylhydrazones as versatile electrophiles for the synthesis of nitrogen-containing compounds. Angew. Chem. Int. Ed., 44, 5176-5186.

44 Brehme, R., Enders, D., Fernández, R. and Lassaletta, J. M. (2007) Aldehyde N,N-dialkylhydrazones as neutral acyl anion equivalents: umpolung of the imine reactivity. Eur. J. Org. Chem., 5629-5660.

45 (a) Dixon, D. J. and Tillman, A. L. (2005) Enantioselective Brønsted acid catalyzed addition reactions of methyleneaminopyrrolidine to imines. Synlett, 2635-2638. (b) Perdicchia, D. and Jørgensen, K. A. (2007) Asymmetric aza-Michael reactions catalyzed by Cinchona alkaloids. J. Org. Chem., 72, 3565-3568. (c) Rueping, M., Sugiono, E., Theissmann, T., Kuenkel, A., Köckritz, A., Pews-Davtyan, A., Nemati, M. and 
Beller, M. (2007) An enantioselective chiral Brønsted acid catalyzed imino-azaenamine reaction. Org. Lett., 9, 1065-1068. (d) Hashimoto, T., Hirose, M. and Maruoka, K. (2008) Asymmetric imino aza-enamine reaction catalyzed by axially chiral dicarboxylic acid: use of arylaldehyde $N, N$-dialkylhydrazones as acyl anion equivalent. J. Am. Chem. Soc., 130, 7556-7557.

46 Pettersen, D., Herrera, R. P., Bernardi, L., Fini, F., Sgarzani, V., Fernández, R., Lassaletta, J. M. and Ricci, A. (2006) A broadened scope for the use of hydrazones as neutral nucleophiles in the presence of $\mathrm{H}$ bonding organocatalysts. Synlett, 239-242.

47 (a) Enders, D., Wortmann, L. and Peters, R. (2000) Recovery of carbonyl compounds from $N, N$ dialkylhydrazones. Acc. Chem. Res., 33, 157-169. (b) Job, A., Janeck, C. F., Bettray, W., Peters, R. and Enders, D. (2002) The SAMP-/RAMP-hydrazone methodology in asymmetric synthesis. Tetrahedron, 58, 2253-2329.

48 (a) Lassaletta, J.-M., Fernández, R., Martín-Zamora, E. and Díez, E. (1996) Enantioselective nucleophilic formylation and cyanation of conjugated enones via Michael addition of formaldehyde SAMP-hydrazone. $J$. Am. Chem. Soc., 118, 7002-7003. (b) Vazquez, J., Prieto, A., Fernández, R., Enders, D. and Lassaletta, J. M. (2002) Asymmetric Michael addition of formaldehyde $N, N$-dialkylhydrazones to alkylidene malonates. Chem. Commun. 498-499. (c) Vázquez, J., Cristea, E., Díez, E., Lassaletta, J. M., Prieto, A. and Fernández, R. (2005) Michael addition of chiral formaldehyde $N, N$-dialkylhydrazones to activated cyclic alkenes. Tetrahedron, 61, 4115-4128.

49 Herrera, R. P., Monge, D., Martín-Zamora, E., Fernández, R. and Lassaletta, J. M. (2007) Organocatalytic conjugate addition of formaldehyde $N, N$-dialkylhydrazones to $\beta, \gamma$-unsaturated $\alpha$-keto esters. Org. Lett., 9 , 3303-3306.

50 Ordóñez, M., Rojas-Cabrera, H. and Cativiela, C. (2009) An overwiew of stereoselective synthesis of $\alpha$ aminophosphonic acids and derivatives. Tetrahedron, 65, 17-49.

51 Palacios, F., Alonso, C. and de los Santos, J. M. (2005) Synthesis of $\beta$-aminophosphonates and phosphinates. Chem. Rev., 105, 899-931.

52 Merino, P., Marqués-López, E. and Herrera, R. P. (2008) Catalytic enantioselective hydrophosphonylation of aldehydes and imines. Adv. Synth. Catal., 350, 1195-1208.

53 (a) Wang, J., Heikkinen, L. D., Li, H., Zu, L., Jiang, W., Xie, H., Wang, W. (2007) Quinine-catalyzed enantioselective Michael addition of diphenyl phosphite to nitroolefins: synthesis of chiral precursors of $\alpha$ substituted $\beta$-aminophosphonates. Adv. Synth. Catal., 349, 1052-1056. (b) Terada, M., Ikehara, T. and Ube, H. (2007) Enantioselective 1,4-addition reactions of diphenyl phosphite to nitroalkenes catalyzed by an axially chiral guanidine. J. Am. Chem. Soc., 129, 14112-14113. (c) Y. Zhu, J. P. Malerich, V. H. Rawal, (2010) Squaramide-catalyzed enantiosective Michael addition of diphenyl phosphite to nitroalkenes. Angew. Chem. Int. Ed., 49, 153-156.

54 Enders, D., Saint-Dizier, A., Lannou, M.-I. and Lenze, A. (2006) The Phospha-Michael addition in organic synthesis. Eur. J. Org. Chem., 29-49. 
55 (a) Bartoli, G., Bosco, M., Carlone, A., Locatelli, M., Mazzanti, A., Sambri, L. and Melchiorre, P. (2007) Organocatalytic asymmetric hydrophosphination of niroalkenes. Chem. Commun., 722-724. (b) Carlone, A., Bartoli, G., Bosco, M., Sambri, L. and Melchiorre, P. (2007) Organocatalytic asymmetric hydrophosphination of $\alpha, \beta$-unsaturated aldehydes. Angew. Chem. Int. Ed., 46, 4504-4506. (c) Ibrahem, I., Rios, R., Vesely, J., Hammar, P., Eriksson, L., Himo, F. and Córdova, A. (2007) Enantioselective organocatalytic hydrophosphination of $\alpha, \beta$-unsaturated aldehydes. Angew. Chem. Int. Ed., 46, 4507-4510. (d) Maerten, E., Cabrera, S., Kjaersgaard, A. and Jørgensen, K. A. (2007) Organocatalytic asymmetric direct phosphonylation of $\alpha, \beta$-unsaturated aldehydes: mechanism, scope, and application in synthesis. J. Org. Chem., 72, 8893-8903.

56 Alcaine, A., Marqués-López, E., Merino, P., Tejero, T. and Herrera, R. P. (2011) Thiourea catalyzed organocatalytic enantioselective Michael addition of diphenyl phosphite to nitroalkenes. Org. Biomol. Chem. 9, 2777-2783.

57 (a) Okino, T., Hoashi, Y. and Takemoto, Y. (2003) Enantioselective Michael reaction of malonates to nitroolefins catalyzed by bifunctional organocatalysts. J. Am. Chem. Soc., 125, 12672-12673. (b) Okino, T., Nakamura, S., Furukawa, T. and Takemoto, Y. (2004) Enantioselective aza-Henry reaction catalyzed by a bifunctional organocatalyst. Org. Lett., 6, 625-627. (c) Okino, T., Hoashi, Y., Furukawa, T., Xu, X. and Takemoto, Y. (2005) Enantio- and diastereoselective Michael reaction of 1,3-dicarbonyl compounds to nitroolefins catalyzed by a bifunctional thiourea. J. Am.Chem. Soc., 127, 119-125.

58 Gaussian 09, Revision A.1, Frisch, M. J., Trucks, G. W., Schlegel, H. B., Scuseria, G. E., Robb, M. A., Cheeseman, J. R., Scalmani, G., Barone, V., Mennucci, B., Petersson, G. A., Nakatsuji, H., Caricato, M., Li, X., Hratchian, H. P., Izmaylov, A. F., Bloino, J., Zheng, G., Sonnenberg, J. L., Hada, M., Ehara, M., Toyota, K., Fukuda, R., Hasegawa, J., Ishida, M., Nakajima, T., Honda, Y., Kitao, O., Nakai, H., Vreven, T., Montgomery, Jr., J. A., Peralta, J. E., Ogliaro, F., Bearpark, M., Heyd, J. J., Brothers, E., Kudin, K. N., Staroverov, V. N., Kobayashi, R., Normand, J., Raghavachari, K., Rendell, A., Burant, J. C., Iyengar, S. S., Tomasi, J., Cossi, M., Rega, N., Millam, N. J., Klene, M., Knox, J. E., Cross, J. B., Bakken, V., Adamo, C., Jaramillo, J., Gomperts, R., Stratmann, R. E., Yazyev, O., Austin, A. J., Cammi, R., Pomelli, C., Ochterski, J. W., Martin, R. L., Morokuma, K., Zakrzewski, V. G., Voth, G. A., Salvador, P., Dannenberg, J. J., Dapprich, S., Daniels, A. D., Farkas, Ö., Foresman, J. B., Ortiz, J. V., Cioslowski, J. and Fox, D. J. (2009) Gaussian, Inc., Wallingford CT.

59 Marqués-López, E., Merino, P., Tejero, T. and Herrera R. P. (2009) Catalytic enantioselective aza-Henry reactions. Eur. J. Org. Chem., 2401-2420.

60 Bernadi, L.; Bonini, B. F.; Capitò, E.; Dessole, G.; Comes-Franchini, M.; Fochi, M.; Ricci, A. (2004) Organocatalyzed solvent-free aza-Henry reaction: a breakthrough in the one-pot synthesis of 1,2-diamines. $J$. Org. Chem., 69, 8168-8171.

61 Ballini, R. and Petrini, M. (2004) Recent synthetic development in the nitro to carbonyl conversion (Nef reaction). Tetrahedron, $\mathbf{6 0}, 1017-1047$. 
62 (a) Westermann, B. (2003) Asymmetric catalytic aza-Henry reactions leading to 1,2-diamines and 1,2diaminocarboxylic acids. Angew. Chem. Int. Ed., 42, 151-153. (b) Ting, A. and Schaus, S. E. (2007) Organocatalytic asymmetric Mannich reactions: new methodology, catalyst design and synthetic applications. Eur. J. Org. Chem., 5797-5815.

63 (a) Song, C. E. (ed) (2009) Cinchona alkaloids in synthesis and catalysis: ligands, immobilization and organocatalysis, Wiley-VCH, Weinheim. (b) Marcelli, T. and Hiemstra, H. (2010) Cinchona alkaloids in asymmetric organocatalysis. Synthesis, 1229-1279. (c) Ting, A., Goss, J. M., McDougal, N. T. and Schaus, S. E. (2010) Brønsted base catalysts. Top. Curr. Chem., 291, 145-200.

64 Bernardi, L., Fini, F., Herrera, R. P., Ricci, A. and Sgarzani, V. (2006) Enantioselective aza-Henry reaction using cinchone organocatalysts. Tetrahedron, 62, 375-380.

65 Pettersen, D., Piana, F., Bernardi, L., Fini, F., Fochi, M., Sgarzani, V. and Ricci, A. (2007) Organocatalytic asymmetric aza-Michael reaction: enantioselective addition of $O$-benzylhydroxylamine to chalcones. Tetrahedron Lett., 48, 7805-7808. 